\title{
Proposal of an Embedded Methodology that uses Organizational Diagnosis and Reengineering: Case of bamboo panel company
}

Eva Selene Hernández Gress, Antonio Oswaldo Ortega Reyes, Jaime Garnica González, José Ramón Corona Armenta Autonomous University of Hidalgo, Engineering Academic Area, Institute of Basic Sciences and Engineering, 42181, Mexico

\begin{tabular}{l} 
A R T I C L E I N F O \\
\hline Article history: \\
Received: 01 June, 2017 \\
Accepted: 28 July, 2017 \\
Online: 24 August, 2017 \\
\hline Keywords: \\
Systemic Diagnosis \\
Reengineering \\
Embedded Methodologies
\end{tabular}

\begin{abstract}
A B S T R A C T
This work is an extension of the Proceedings of the International Conference on Industrial Engineering, Management Science and Applications, which presented some of the phases of Reengineering applied to Bamboo Panel Company; the results were Strategic planning, Systemic Diagnosis and Performance Indicators through the Balanced Scorecard. Now, the main purpose of this article is to present a methodology that embedding Organizational Diagnosis and Reengineering, which emphasizes the incorporation of culture, context, management style, and knowledge as well as inner and outer actors. The results of the proposed methodology applied to the case study are included, up to the moment of the writing of this article. Future work consists on the development of strategies for Innovation as a strategy planned in the Balanced Scorecard and derived from the embedded methodology.
\end{abstract}

\section{Introduction}

This paper shows a subsequent development of the work "Systemic Diagnosis and Strategy-Based Performance Indicators. Bamboo Panel Company Case" exposed at the 6th International Conference on Industrial Technology and Management [1]. The paper came from the project called "Product Development of Modular Components with Prefabricated Bamboo, Phase II". It was part of the Program for Research Stimulation, Technological Development and Innovation of the NATIONAL COUNCIL OF SCIENCE AND TECHNOLOGY (CONACYT, in Mexico). This project was developed by the Autonomous University of Hidalgo in Mexico and a private Enterprise.

The project was carried out from March 2016 to April 2017. It included physical prototypes, procedure manuals, mapping of facilities distribution, simulation of the production systems as well as performance indicators systems, among others.

The paper focuses on the section of methodology, especially, the one that concerns Strategic Planning: Systemic Diagnosis and Performance Indicators following the basis of the Balanced Scorecard, since them conflux to the main perspectives of this stage of development: embedding organizational diagnosis and reengineering processes. Other deliverables include prototypes and development of technology, but they shall not be exposed since

\footnotetext{
*Corresponding Author: Antonio Oswaldo Ortega Reyes, Autonomous University of Hidalgo, Engineering Academic Area, Institute of Basic Sciences and Engineering, 42181, Mexico | Email: oswwaldoo@yahoo.com.mx
}

that is confidential information. For the same reasons, the name of the company is not disclosed. The company, in which the case study was carried out, designs and constructs structures using bamboo as a raw material. This company creates and executes innovative projects, products and services, from the perspective of sustainability, combining artisan techniques with technologies that allow low environmental impact seeking also, a high social impact. A highlight is that the tool of reengineering was followed for the development of the bamboo prefabricated panel processes.

An organizational diagnosis was performed under the systemic approach, in order to identify the problems of the organization and for the creation of performance indicators. For this, it was necessary to create the so called embedded methodology combining reengineering and organizational diagnosis tools considering the enterprise as a system.

There are many diagnostic tools, however, the methodological design for the diagnosis was the one proposed by Ortega [2], which embeds a systemic perspective and incorporates ad hoc tools according to the situation of the organization, in this case, technology, organization, production, environmental conditions and regulatory frameworks. Additionally, the diagnosis comes to be a component of the Strategic Planning that serves to make decisions.

The first step consisted on stablishing the scope of the diagnosis. For this purpose, the different areas of the organization were analyzed following the methodology proposed by Ortega [2] shown in Figure 1. 


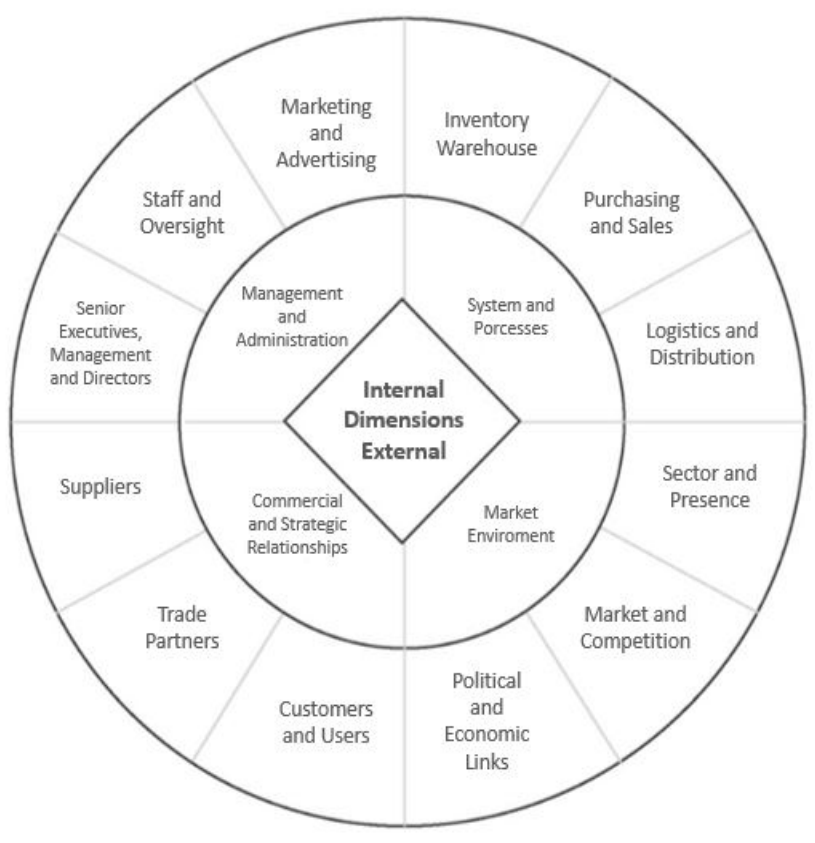

Figure 1. Dimensions and useful techniques. Source: Author's elaboration

The second step was to define the dimensions and useful techniques of the intervention which were also defined following this author (Figure 2).

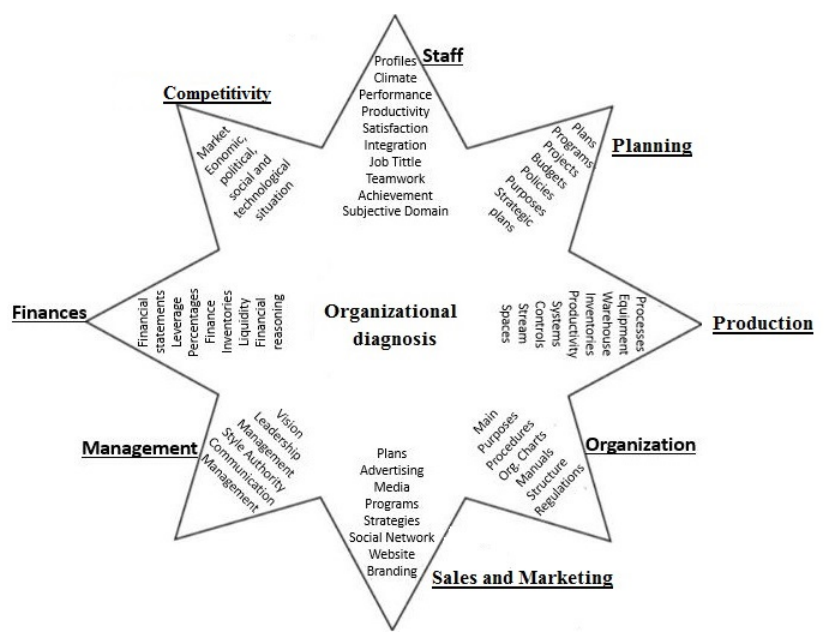

Figure 2. Organizational diagnosis.Source: Author's elaboration

The resultant was a diagnostic map divided into External and Internal, aspects that were also included in the methodological proposal (Figure 3).

Then the tool of the Balanced Scorecard (BSC) was used to integrate the areas of the research process in a Strategic Map [1]. The BSC is a model that becomes a very useful tool for strategic management. It is based on the definition of strategic objectives, indicators and strategic initiatives, establishing relationships by a strategic map in four basic perspectives: financial, clients, internal processes and learning and growth, then the strategy should be translated directly into objectives; where it will be measured through indicators and aligned with initiatives. Success at implementing the BSC depends on the participation of people from different levels and areas of the organization. Kaplan and Norton
[3] designed the Balanced Scorecard as an instrument to measure results, based on the establishment of financial and non-financial indicators derived from the company's vision, mission and strategy, making it a tool to manage the strategy.
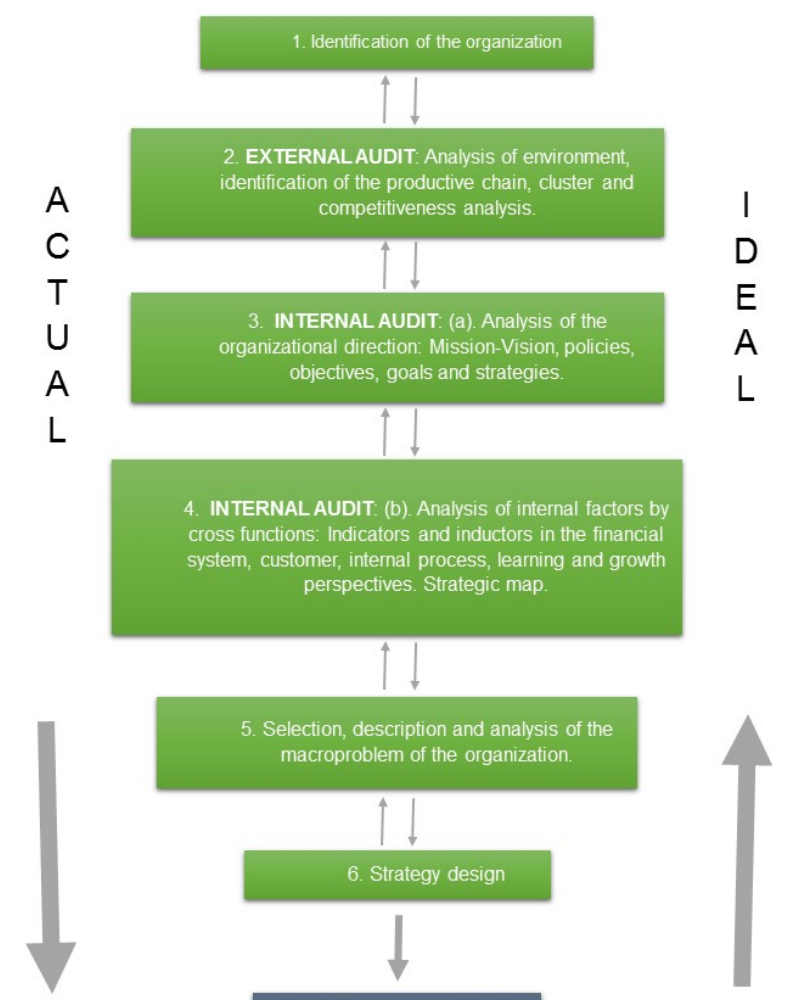

NEW STRATEGICAL PLAN

Figure 3. Diagnostic map. Source: Author's elaboration

Some of the benefits of implementing the BSC in organizations are: aligning employees to the company's vision, improving communication to all the staff and compliance, redefining the strategy based on results presented, a translation of the vision and the strategy into actions, which are oriented towards the creation of value; it is integrated with the information of all the areas of the organization and also the capacity of analysis and the decision making is improved. A strategic map as a resultant outcome [4], presents in a simple and coherent way the description of an organization's strategy, in order to establish the objectives and indicators in the financial, customer, internal processes and learning and growth perspectives.

The financial perspective describes the tangible results of the strategy in traditional financial terms, indicators such as the profitability of the investment, shareholder value, revenue growth, unit costs, among others; thus, measuring the creation of value for the organization. The customer perspective, reflects the positioning of the organization in the market, identifying the customer segments and, defines the value proposition for the target customers. Rodiles and Fuentes [5] mention the indicators which are generally considered: customer satisfaction and retention, as well as the acquisition of new customers, customer profitability and market participation where the organization participates. The 


\section{E. S. H. Gress et al. / Advances in Science, Technology and Engineering Systems Journal Vol. 2, No. 3, 1626-1633 (2017)}

internal process perspective identifies internal processes that will have a greater impact on customer satisfaction. Some indicators of this perspective are: productivity, quality and innovation of products and services. The perspective of learning and growth is based on the fact that the formation and growth of an organization come mainly from people, systems and processes. According to Altair Consulting Group [6], the objectives of this perspective are to identify the human capital, systems and organizational climate required to support value creation processes.

Balanced Scorecard has evolved from its early use as a simple performance measurement framework to a full strategic planning and management system. Balanced Scorecard is used by many successful businesses all around the world [7], [8].

\section{The Bamboo Industry in Mexico}

According to Estrada [9], the Mexican manufacturing industry is investing little in Research and Development activities and the poor resultants of these investments are concentrated in few sectors as: cars, glass, cement as well as office and electronic equipment. Therefore, there is a huge need to encourage new technologies in alternate areas of the economy, so the industrial platform can take off.

In the case of the industry of Bamboo in Mexico the general situation reflects the opportunity for this sector to grow. Nowadays the use of bamboo in Mexico is not very exploited and companies that use it as raw material are limited to decorative purposes only such as walls, floors and partition panels in simple constructions. Nevertheless, there are some states in Mexico with the optimal conditions to have bamboo plantations such as Veracruz, Chiapas and Puebla. Bamboo is known as "one of the most surprising plants in nature", known as "the plant of the thousand uses" because from it, food, clothing, construction material, pulp for paper and medicines, among others can be obtained. In Mexico, bamboo is used in the construction of rural dwellings, in the manufacture of handicrafts, furniture and home accessories, also for medicinal and ornamental purposes.

For this study, the enterprise was a local producer of Bamboo constructions such as cabins, docks, pergolas, storage rooms and specialized designs which are manufactured in this medium company. The business was created in 2011 and has participated in several government programs with the purpose of developing the technology of its processes and improving its quality and profitability. One of the supports the company received was a special funding from the Mexican National Council of Science and Technology with the participation of a public university, in order to aid the enterprise to create an innovative process for the massive production of bamboo panels. This is the framework that budgeted and allowed the development of this project, which started with an organizational diagnosis process and included a reengineering purpose, embedding both perspectives in the creation of innovative production processes.

\section{Problem situation}

Nevertheless the organizational diagnosis, was intended to identify the difficulties and opportunity areas of the company, there were some symptoms which pointed to specific problems: lack of a well-defined organizational structure, lack of clarity about the product benefits and its uses, an inexistent trading strategy, non-structured procedures which led the production to artisan and non-standardized products, organizational ends not clearly established, an inappropriate layout, and confusing management styles.

So, the problem statement for this study was that, at the moment of the project, the company did not have formal procedures, documents and a business strategy which allowed it to develop its operations under a quality and innovation style that responded to the requirements of its sector and market.

Therefore, it was necessary to set a way to identify, analyze and combine tools of problem solving, work improvement and processes engineering such as organizational diagnosis and reengineering. Reengineering is a methodology whose principles are used to implement other philosophies such as Total Quality Control [10].

\section{Reengineering}

Reengineering is "the notion of discontinuous thinking -of recognizing and breaking away from the outdated rules and fundamental assumptions that underlie operations" [11]. Reengineering processes require analysis of managerial efficiency. Welsch, Hilton, Gordon and Rivera mention that the efficiency of an entity is generally recognized as the single most important factor in long-term success. The success of the organization is measured in terms of achieving its goals. For this, it is necessary to implement the activities through the efficient use of human, material and financial resources. That is why it is important to develop and implement the process of planning, organizing, directing and controlling. "Business process improvement is about analyzing the current behavior of process execution in order to identify the process inefficiencies such as agent assignment, resource utilization, and control flow" [12].

To begin with the administrative process, the first phase is planning, which consists of defining what will be done, how to do it and who will. It implies defining the vision, mission, strategies, objectives, goals, actions and initiatives, as well as the allocation of human, material and financial resources for the implementation, monitoring and continuous improvement of the organization. In order to achieve this, it is necessary to develop the strategic plan. This document demands the consideration of the current and desired situation for its construction and defines the strategy.

The holistic view of this managerial approach was understood following the spots of organizational diagnosis.

\section{Organizational diagnosis}

There have been many scholars who have defined the concept; however, the following definitions were suitable for the theoretical framework of this study. According to Vidal [13], it is "the process of comparison between two situations: the present, which we have come to know through inquiry, and another already defined and supposedly known that serves as a guideline or model". Porter [14], points out that the competency analysis consists of four diagnostic components: future goals, current strategy, assumptions and capabilities. Savall and Zardet [15] highlight that a socioeconomic diagnosis aims "to make the inventory of the dysfunctions and calculate the hidden costs that they originate", and add that the diagnosis is based on three sources of information: interviews, direct observations, and document analysis. Audirac, et. al. [16] refer that "the diagnosis consists of obtaining valid 


\section{E. S. H. Gress et al. / Advances in Science, Technology and Engineering Systems Journal Vol. 2, No. 3, 1626-1633 (2017)}

information about the organization. It involves collecting and analyzing information about the culture, processes, structure and other essential elements of the organization". Finally, the definition of Ortega [2], established the organizational diagnosis as "the action and effect of specifying the state that an organization keeps from the identification and understanding of its signs and symptoms".

From these definitions and theoretical framework, it was possible to propose a methodological design to diagnose and reengineer the company of this study.

\section{Embedded Methodology for the organizational diagnosis in the bamboo industry}

The methodological design started from considering the situation of the company as a unique case study. Each case study presents its own features due to its culture, context, management style, knowledge as well as inner and outer actors, which altogether lead to the application of discerned, adjusted analyzes that incorporate these characteristics. Therefore, the methodological design was sustained by different approaches and techniques which have been successfully used in different areas. So, to describe the current conditions of the company, this research used observation, documentary revision, survey and interview, as data collection techniques, with the instruments of field diary, data sheets, questionnaire, focus groups and semi-structured guides [17]. Also, the investigation was considered non-experimental since there was no variables manipulation, and only the facts as they were developed, were observed and described [18].

Therefore, we started form a holistic methodological approach based in the general system theory and particularly in the methodology of soft systems of Checkland [19], that sets the status of a given problem situation, to be then contrasted with the ideal state though the systemic thinking. We designed the diagnostic intervention and we also used benchmarking for the contextual analysis and systemic diagnosis, in order to perform an internal and external auditing of the company. To be able to understand the problems of the organization, a Balanced Scorecard setting was useful in order to align the vision and strategy of the company with the objectives and initiatives. For the application of techniques, a team of five observers was formed, who used audio and video recording equipment as well as observation rooms. The methodological strategy considered a qualitative design applied on March 2016 at the enterprise, which is located in Mexico City, where we worked with local suppliers of this company. The actions performed were:

1. Documentary analysis to formulate a sectorial context at international, national levels through information sources such as sectorial indexes, web pages of companies and videos on internet.

2. Field work through "in situ" inspections that included the applications of the following techniques:

- Observation guide about planning, organization, management aspects and control of the enterprise.

- Focus group with the main suppliers of the enterprise to determine the competitiveness of an organization and its productive chain.
- Technique of Nominal Groups for the revision of the mission and vision, creation of the policies, strategies, objectives and initiatives [20].

- A focus group with the employees of the company, who also answered the tool of Organizational Health Checkup.

3. Cabinet study for the integration, analysis and synthesis of information collected with the following phases:

- Design of a cluster for the enterprise.

- Writing the mission and vision, creating policies, strategies, objectives and initiatives.

- Drafting of the Balanced Scorecard and creation of the Strategic Map for the Company.

Following these settings, an organizational proposal of the methodology was established dividing the involved elements into endogenous and exogenous, considering the actions of organizational diagnosis as inner activities and the reengineering processes as strategic tasks. These, allowed us to include the perspective of intrinsic and extrinsic influence factors in the activity of the enterprise, and embed the theoretical aspects of reengineering and organizational diagnosis as shown in Figure 4.

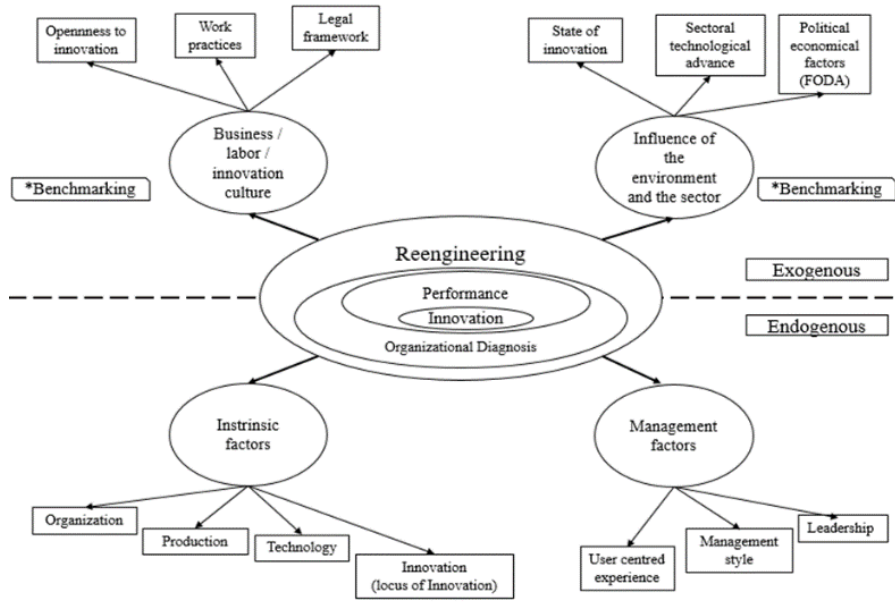

Figure 4.Embedded Methodology for the organizational diagnosis in the bamboo industry. Source: Author's elaboration

Following this design, data gathering and data analysis led us to the following results and discussion.

\section{Results and discussion}

\subsection{Diagnostic Results}

To begin with the diagnosis, an evaluation of the environment is required. Environment refers to the set of people, organizations, institutions, objects or elements of any nature, which are outside the company, have some significance for it. For this purpose, the production chain of the enterprise was identified by conducting a focal group interview where suppliers, subcontractors, distribution channels, transport, communication technologies, direct competitors, sector barriers and customers were required.

The mission of the Company is to: Minimize environmental impact and maximize social impact, taking up vernacular construction techniques and enhancing them with innovative technologies. 


\section{E. S. H. Gress et al. / Advances in Science, Technology and Engineering Systems Journal Vol. 2, No. 3, 1626-1633 (2017)}

In general, it is observed that the mission is structured in an appropriate way, although it is to point out that the enterprise should review its geographical scope and develop strategies at local, regional or international levels. As a conclusion, it is clear they are still working in a stage of growth.

The vision of the enterprise is: To be in 2020 a leading company in the sustainable construction market, through the fusion of vernacular techniques with innovative technological developments.

The vision and mission were reviewed. In addition, the establishment of strategies and policies was done using a nominal group technique. This session was attended by executives and employees of the Company. The Technique of Nominal Groups allows a working group to reach a consensus on some subject, according to their level of importance and according to priorities established by the group [20].

The vision remained the same; but the mission, was adjusted as follows: To minimize environmental impacts and maximize social impacts, taking up vernacular construction techniques and enhancing them with innovative technologies, where our employees carry out a specialized monitoring in each of the stages of the cycle life of products.

After applying the technique of nominal groups the generic strategy for the enterprise was précised as the differentiation since it is desired to:

- Create a product and / or service that is perceived as unique.

- Work in design, brand image, technology, customer service, dealer chain, high quality, etc.

- New product design with high quality materials.

- Intense customer support by providing specialized followup at each stage of the product life cycle.

\subsection{Balanced Scorecard results}

Some specific aspects that were taken into account for the creation of the Integral Chart of the Company contemplating important aspects defined during the Systemic Diagnosis included:

- The alignment of the personal goals of all employees should have with the company's strategy [21]. So employees were asked to write their goals according to the company strategy.

- The value of intangible assets such as knowledge and technology that have a direct impact on income and profits. In this case the investment which is making innovation and technology is of vital importance. Innovation focused companies must offer products and services whose performance exceeds the competitors in which the customer values.

Since the Company is starting with mass production, in the manufacturing aspect, simple indicators such as on-time delivery, customer waiting time, number of reworks, defect rates, cycle times, etc., were presented.

The Balanced Scorecard remained for the company to align the objectives of the employees and directors with the strategy, and to carry out the plan of operation and revision. With this strategy in mind, and the important aspects to consider, the strategic map, the objectives and the initiatives of the Balanced Scorecard, the results and the initiatives developed are in [1] considering the proposal of [4].

\subsection{Management style}

The Pareto principle establishes a distinction between the aspects that require greater attention and that have greater impact in the organization, discriminating those with less impact. It allows to discriminate the few vital issues of the trivial many. After data gathering with surveys and interviews, a Pareto graphic was formulated showing the most important problems in the management style in Table 1 and Figure 5. This was one of the reasons why the use of Reengineering in the case study is justified because one of the strongest problems they face is organizational and this factor has been shown to have a very strong relationship with reengineering aspects [22].

Table 1. Data for the Pareto Chart, Source: Author's elaboration.

\begin{tabular}{|c|c|c|c|c|}
\hline $\begin{array}{l}\text { Problems } \\
\text { mentioned }\end{array}$ & $\begin{array}{l}\text { Sort } \\
\text { Data }\end{array}$ & $\begin{array}{c}\text { Number of } \\
\text { Accumulated } \\
\text { Defects }\end{array}$ & $\begin{array}{c}\% \\
\text { Total }\end{array}$ & $\begin{array}{c}\% \\
\text { Accumulated }\end{array}$ \\
\hline Organization & 10 & 10 & 23.80952381 & 23.80952381 \\
\hline Communication & 10 & 20 & 23.80952381 & 47.61904762 \\
\hline Decisions & 7 & 27 & 16.66666667 & 64.28571429 \\
\hline Time & 6 & 33 & 14.28571429 & 78.57142857 \\
\hline $\begin{array}{l}\text { Management of } \\
\text { staff }\end{array}$ & 3 & 36 & 7.142857143 & 85.71428571 \\
\hline Planning & 2 & 38 & 4.761904762 & 90.47619048 \\
\hline Commitment & 2 & 40 & 4.761904762 & 95.23809524 \\
\hline $\begin{array}{c}\text { Work } \\
\text { environment }\end{array}$ & 2 & 42 & 4.761904762 & 100 \\
\hline & 42 & & & \\
\hline
\end{tabular}

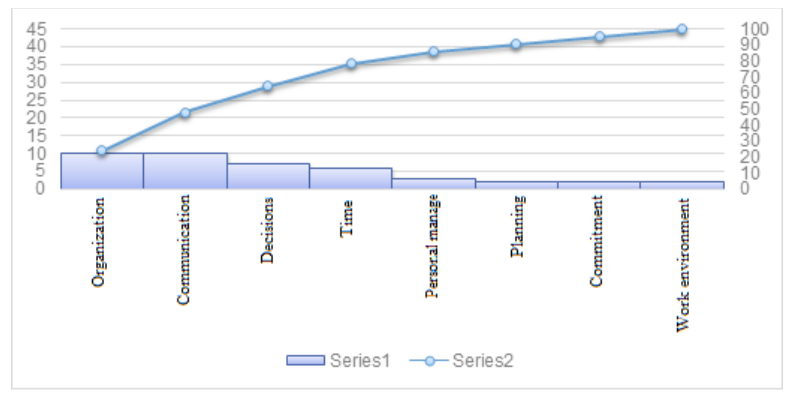

Figure 5. Pareto Chart. Source: Author's elaboration.

Thus, according to the graph of the total of problems detected and confirmed by different techniques, those of greater weight for the correct operation of the company were the organization, the communication and the decision making.

\subsection{SWOT Matrix}

In addition to the Benchmarking carried out in [1], the SWOT (strengths, weaknesses, opportunities, and threats)is a structured 


\section{E. S. H. Gress et al. / Advances in Science, Technology and Engineering Systems Journal Vol. 2, No. 3, 1626-1633 (2017)}

planning method that evaluates those four elements in the organization. It was built with all the elements of the Diagnosis, in this sense 10 employees of the company were asked to vote for the most significant aspects. The results are shown below:

Table 2. SWOT Matrix. Source: Author's elaboration.

\begin{tabular}{|c|c|}
\hline Forces & Weaknesses \\
\hline $\begin{array}{l}\text { 1. The company is concerned about } \\
\text { the environment, which means that it } \\
\text { has sustainable products } \\
2 \text {. The constant innovation in } \\
\text { products. } \\
\text { 3. Their products are unique in our } \\
\text { country. } \\
4 \text {. The architectural projects that } \\
\text { have been carried out so far have a } \\
\text { harmonious design. } \\
5 \text {. The structural and seismic tests } \\
\text { performed on constructions with } \\
\text { bamboo panels are favorable. } \\
6 \text {. Its management for the search of } \\
\text { economic funds is good. } \\
\text { 7. The presence of the company in } \\
\text { associations dedicated to sustainable } \\
\text { construction }\end{array}$ & $\begin{array}{l}\text { 1. The shared leadership and the } \\
\text { different ideas of the owners of } \\
\text { the organization. } \\
\text { 2. The lack of market certainty } \\
\text { for this type of constructions. } \\
\text { 3. The lack of customer follow- } \\
\text { up. } \\
\text { 4. The company do not have } \\
\text { defined processes, nor } \\
\text { standardize. } \\
5 \text {. Its processes of production are } \\
\text { handicraft which makes massive } \\
\text { production impossible. } \\
\text { 6. There is high turnover in staff, } \\
\text { which causes them to waste time } \\
\text { in training them. }\end{array}$ \\
\hline $\begin{array}{c}\text { Threats } \\
\end{array}$ & Opportunities \\
\hline $\begin{array}{l}\text { 1. Supplier relationships are not } \\
\text { narrow, making it difficult to } \\
\text { implement some manufacturing } \\
\text { systems. } \\
2 \text {. The company has no market } \\
\text { share. There is not even a market for } \\
\text { what is intended to be } \\
\text { commercialized. } \\
\text { 3. There are companies that are } \\
\text { already manufacturing other } \\
\text { products with bamboo, especially } \\
\text { decorative walls and floors that } \\
\text { could venture into the design and } \\
\text { construction of houses. } \\
4 \text {. Creation of microenterprises with } \\
\text { the same turnaround due to } \\
\text { unemployment, since the } \\
\text { unemployment rate in the country } \\
\text { during the second quarter of } 2016 \\
\text { was } 3.9 \% \text { of the Economically } \\
\text { Active Population and although it is } \\
\text { lower than in } 2015 \text { with } 4.3 \% \text {, This } \\
\text { one is in constant dynamism. } \\
5 \text {. The annual inflation rate, which } \\
\text { currently stands at } 2.88 \% \text {, and } \\
\text { because it is rising, makes it difficult } \\
\text { each day to buy its inputs as well as } \\
\text { the stability of the prices of its } \\
\text { products. }\end{array}$ & $\begin{array}{l}\text { 1. The support that many } \\
\text { institutions grant to companies } \\
\text { that minimize environmental } \\
\text { impact (CONACYT and public } \\
\text { universities). } \\
\text { 2. Currently, until the moment of } \\
\text { the investigation, no other } \\
\text { company located in Mexico was } \\
\text { found on the Internet to do the } \\
\text { same. } \\
\text { 3. The company has strived to } \\
\text { develop sustainable technology } \\
\text { and products for the construction } \\
\text { of its products. } \\
\text { 4. Mexico in many states is } \\
\text { suitable for planting bamboo, } \\
\text { which could benefit the company } \\
\text { by having high quality raw } \\
\text { material. } \\
5 \text {. The closeness with the United } \\
\text { States of America that accepts } \\
\text { well the construction with } \\
\text { prefabricated wood panels. The } \\
\text { possible devaluation of the peso } \\
\text { may facilitate exports. } \\
6 . \text { Manufacture other bamboo } \\
\text { products that are already } \\
\text { accepted as decorative walls, } \\
\text { partition panels, floors. } \\
7 . \text { Carry out a cluster with civil } \\
\text { associations and municipal } \\
\text { governments that carry out } \\
\text { decent housing in marginalized } \\
\text { areas. } \\
8 \text { The company is behaving } \\
\text { adequately for the business phase } \\
\text { in which it is: Growth, dedicating } \\
\text { itself to the development and } \\
\text { identification of new products } \\
\text { and services, expanding facilities } \\
\text { and investing in infrastructure } \\
8 . \text { Increased demand for housing } \\
\text { at the national level, in } 2015 \text { was } \\
1159,480 \text { households and during } \\
\text { the current year is estimated to be } \\
\text { 1'166,872 households. }\end{array}$ \\
\hline
\end{tabular}

This served to evaluate if the strategy of the organization and the objectives set out in the Balanced Scorecard, are correctly defined, in addition to identifying aspects such as management style and influence of the environment.

\section{Innovation}

The innovation approach followed for the bamboo industry in this study was, the one proposed by Belay-Endalamaw [23], who suggests identifying at first the innovation scope, according to the following typology:

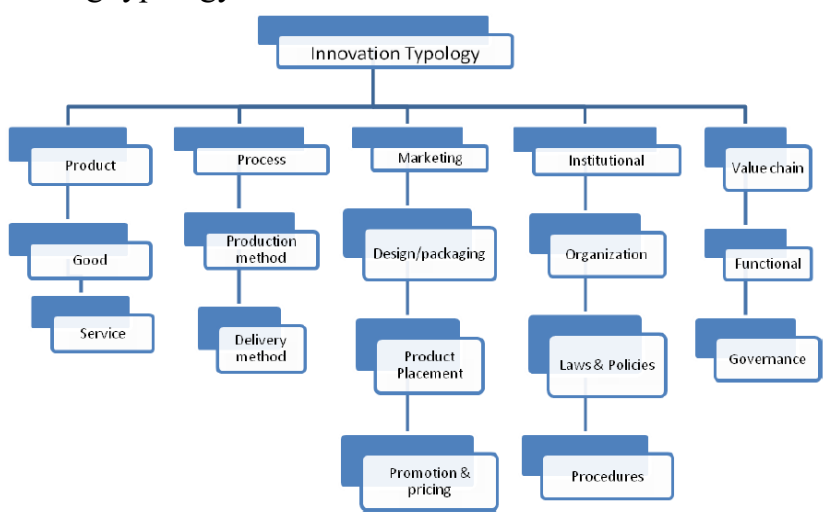

Figure 6. Innovation Typologies [24]

\section{Reengineering results}

Once the mission, vision, strategy and policies were defined, the organization chart and the job manual were built. Figure 8 shows the organizational chart and in Figure 2, as an example, a position of the manual: project coordinator.

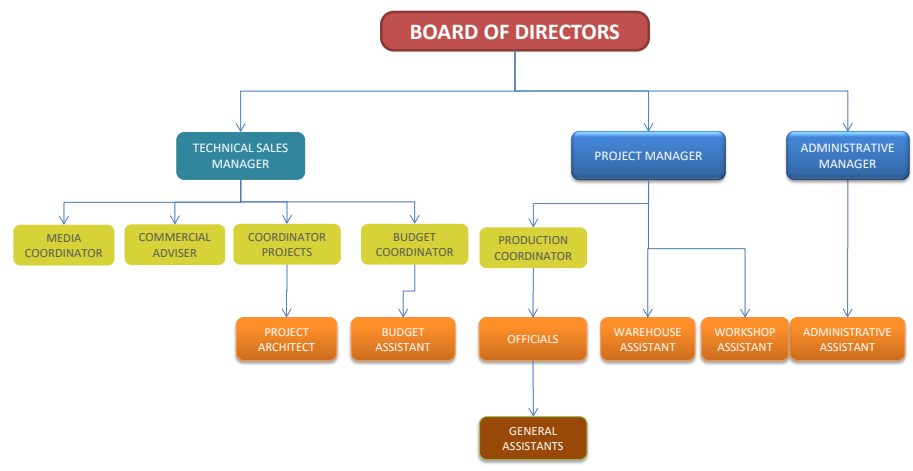

Figure 7. Organization chart of the company. Source: Author's elaboration.

Then, in order to establish the proper features of work positions and to reorganize communication flows and tasks, a manual of positions was developed.

The foregoing supports the development of manual procedures, which serves as a means of communication and coordination between different levels of a company. The procedures manual describes routine work tasks, describing the procedures used within the organization and the logical sequence of each activity, to unify and Control work routines and to avoid their arbitrary alteration. It also helps the supervision of standardization activities, avoiding duplication of functions and unnecessary steps within processes, facilitates the work of the 
administrative audit, the evaluation of internal control and its monitoring.

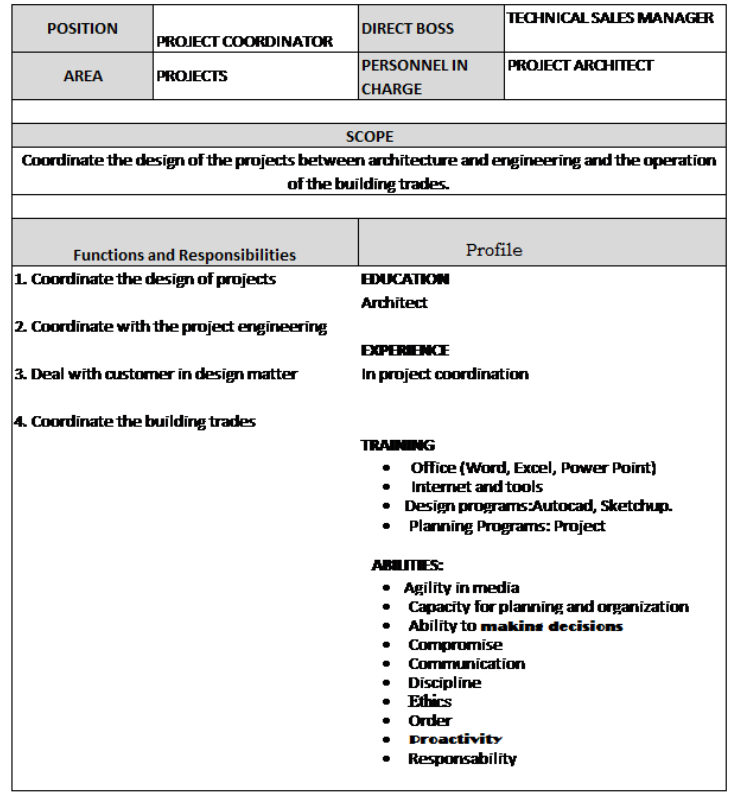

Figure 8. Position of Project coordinator, in the manual of positions. Source: Author's elaboration.

The proper structuring of the manual should reflect the specific activities carried out, as well as the means used to obtain the objectives, while facilitating the execution, monitoring and evaluation of organizational performance. This should be an instrument that supports the process of updating and improvement, by simplifying the procedures that allow the proper and efficient performance of the assigned function. The manual has a general objective, the specific ones by the procedure and the norms of operation. Only the purchasing process is displayed in Figure 9 and Figure 10.

\begin{tabular}{|c|c|c|c|}
\hline 1 & Warehouse assistant & Receives a copy of the purchase order & Purchase order CBW01 \\
\hline 2 & & $\begin{array}{l}\text { Checks copy of purchase order, identify product and verify } \\
\text { matching purchase order, invoice and product }\end{array}$ & CBW01 \\
\hline 4 & General Assistant & $\begin{array}{l}\text { Unloads and counts the products, entering the quantity on the raw } \\
\text { material registration sheet }\end{array}$ & $\begin{array}{l}\text { Raw material registration } \\
\text { sheet PBW04 }\end{array}$ \\
\hline 5 & Warehouse assistant & $\begin{array}{l}\text { Inspects that the raw material meets the required specifications, } \\
\text { according to the raw material quality control guide }\end{array}$ & $\begin{array}{l}\text { Raw material quality control } \\
\text { guide PBW05 }\end{array}$ \\
\hline 6 & & $\begin{array}{l}\text { Compares the information on the raw material registration sheet } \\
\text { with the purchase order information. }\end{array}$ & $\begin{array}{l}\text { Purchase order and raw } \\
\text { material registration sheet } \\
\text { CBW01, PBW04 }\end{array}$ \\
\hline 7 & & Do the products and quantities match? & \\
\hline 8 & & Affirmative. Go to Activity 10 & \\
\hline 9 & & Negative. Retum the raw material to the supplier. & \\
\hline 10 & & $\begin{array}{l}\text { Signatures of incidence on the raw material registration sheet } \\
\text { and if necessary to return it to the supplier. }\end{array}$ & $\begin{array}{l}\text { Raw material registration } \\
\text { sheet PBW04 }\end{array}$ \\
\hline 11 & & Signatures of conformity on the raw material registration sheet. & $\begin{array}{l}\text { Raw material registration } \\
\text { sheet PBW04 }\end{array}$ \\
\hline 12 & & Determines to which warehouse carry the product & \\
\hline 13 & & Coordinates product income & \\
\hline \multirow[t]{2}{*}{14} & General Assistant & $\begin{array}{l}\text { Transports the goods from the vehicle to the inside of the } \\
\text { warehouse }\end{array}$ & \\
\hline & Warehouse assistant & $\begin{array}{l}\text { Accommodates and classifies the raw material entered into the } \\
\text { warehouse }\end{array}$ & \\
\hline
\end{tabular}

Figure 9. Example of the procedure of purchasing process, in the Manual of procedures. Source: Author's elaboration.

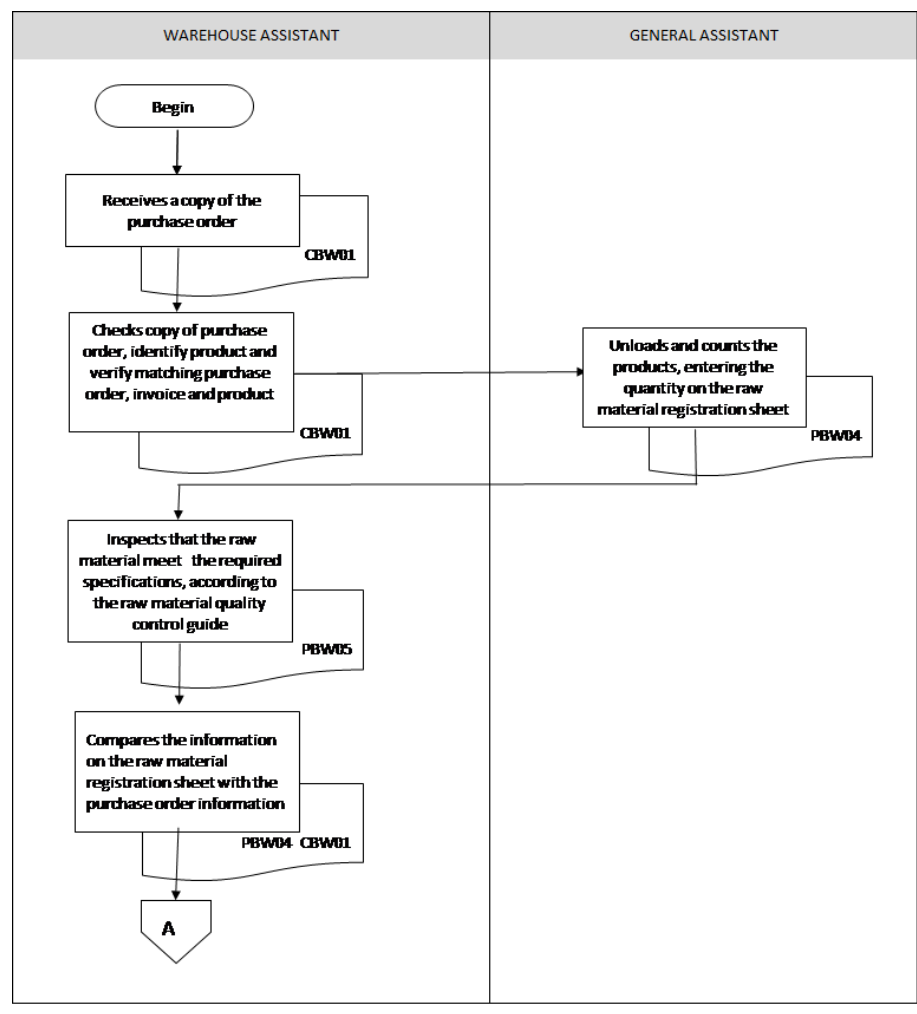

Figure 10. Purchasing process, graphic representation. Source: author's elaboration.

So, after showing evidence of the developments and results of embedding the approaches of organizational diagnosis and reengineering, a summary a table with different approaches considering in both methodologies are shown in Table 3.

\section{Conclusions}

This project was carried out since March 2016 in a medium company dedicated to the development of bamboo structural panels. In the "Diagnosis", something that was observed is the company did not have a strategic plan, so they proceeded to review their vision and mission. Their policies were generated and the strategy was also determined. Another of the deliverables was the "Performance Indicators", but they were not intended to establish solely the relation to the productive process; they were indicators that really aligned the organization with its strategy to lead it to achieve its vision. The Balanced Scorecard gathers indicators from four perspectives: Customer, Employees, Internal Business Process and Finance and developed clear and measurable objectives in each of these items so that the company can achieve its vision through the differentiation of its product and service [1].

In this article an extension was discussed embedding two methodologies: System Diagnosis and Reengineering, considering exogenous and endogenous factors, innovation culture, influence of the environment, management and another intrinsic values like organization and culture. Some results in a bamboo company are shown in order to validate this methodology. The most important is the use of System Diagnosis and Reengineering to achieve innovation as performance indicator to consolidate the company strategic planning.

Some initiatives to achieve the objectives have already been worked out such as employee training in 5 's, revision of the 


\section{E. S. H. Gress et al. / Advances in Science, Technology and Engineering Systems Journal Vol. 2, No. 3, 1626-1633 (2017)}

organization chart and job profile, creation of workshops that bring the Company closer to its suppliers, creation of the manual of processes, among others. However some pending includes the development and implementation of the proper facility layout; implementation of the automated assembly machine, among others

Future work should be aimed at validating the proposal of an inner culture of innovation and its evaluation.

Table 3. Summary of Techniques. Source: Author's elaboration.

\begin{tabular}{|c|c|c|}
\hline & Tools/techniques & Description for application \\
\hline \multirow[t]{8}{*}{$\begin{array}{c}\text { System } \\
\text { Diagnosis }\end{array}$} & $\begin{array}{l}\text { Organizational Health } \\
\text { Check up }\end{array}$ & Employees of the company \\
\hline & Focus group & $\begin{array}{l}\text { Main suppliers of the enterprise } \\
\text { to determine the } \\
\text { competitiveness of an } \\
\text { organization and its productive } \\
\text { chain. }\end{array}$ \\
\hline & $\begin{array}{l}\text { Technique of Nominal } \\
\text { Groups }\end{array}$ & $\begin{array}{l}\text { Revision of the mission and } \\
\text { vision }\end{array}$ \\
\hline & Observation guide & $\begin{array}{l}\text { Planning, organization, } \\
\text { management aspects and } \\
\text { control of the enterprise. }\end{array}$ \\
\hline & Interview & Data collection techniques \\
\hline & Survey & Data collection techniques \\
\hline & Pareto Graphic & $\begin{array}{l}\text { Shows the most important } \\
\text { problems in the management } \\
\text { style. }\end{array}$ \\
\hline & SWOT Matrix & $\begin{array}{l}\text { Serves to evaluate if the } \\
\text { strategy of the organization and } \\
\text { the objectives set out in the } \\
\text { Balanced Scorecard, are } \\
\text { correctly defined, }\end{array}$ \\
\hline \multirow{4}{*}{ Reengineering } & Balanced Scorecard & $\begin{array}{l}\text { It is based on the definition of } \\
\text { strategic objectives, indicators } \\
\text { and strategic initiatives, } \\
\text { establishing relationships by a } \\
\text { strategic map in four basic } \\
\text { perspectives: financial, clients, } \\
\text { internal processes and learning } \\
\text { and growth, then the strategy } \\
\text { should be translated directly } \\
\text { into objectives. }\end{array}$ \\
\hline & Manual procedures & $\begin{array}{l}\text { Serves for communication and } \\
\text { coordination between different } \\
\text { levels of a company }\end{array}$ \\
\hline & Manual of positions & $\begin{array}{l}\text { Define the proper features of } \\
\text { work positions and to } \\
\text { reorganize communication } \\
\text { flows and tasks }\end{array}$ \\
\hline & Innovation & $\begin{array}{l}\text { The forms of innovation } \\
\text { included in this study were } \\
\text { product, process and } \\
\text { organizational innovation. }\end{array}$ \\
\hline
\end{tabular}

\section{References}

[1] Hernández E. et. al."Systemic Diagnosis and Strategy-Based Performance Indicators :Bamboo Panel Company Case". Proceedings of 2017 the 6th International Conference on Industrial Technology and Management (ICITM 2017).Cambridge, UK.ISBN: 978-1-5090-5328-5, pp. 123-133

[2] O. Ortega. "Elementary My Dear Consultant: Sherlock Holmes-style organizational diagnosis". Mexico: Patria Publishing Group, 2015. (Original in Spanish: Elemental mi querido consultor: Diagnóstico organizacional al estilo Sherlock Holmes)

[3] R. Kaplan and D. Norton. "The Balanced Scorecard: Measures that Drive Performance". Harvard Business Review, January-February, 1992, 71-79.
[4] R. Kaplan and D. Norton. Conceptual Foundations of the Balanced Scorecard. Harvard Business School Press, 2010.

[5] Electronic Publication: www.fip.unam.mx/simposio_investigacion2dic04/el_cuadro_extenso.html. 2004. Recovered in October 2016. Authors: Rodiles and Fuentes

[6] ALTAIR CONSULTING GROUP. "Balanced Scorecard".Economía Journal, 3:150, 2005. (Original in Spanish: Cuadro de Mando Integral)

[7] Lesakova L. and Dubcováb K. Knowledge. "Use of the Balanced Scorecard Method in the Businesses in the Slovak Republic". Procedia-Social and Behavorial Sciences. Proceedings of the 3rd International Conference on New Challenges in Management and Organization: Organization and Leadership, 2 May 2016, Dubai, UAE, Elsevier.

[8] Kalendera Z and Vayvay O. "The Fifth Pillar of the Balanced Scorecard: Sustainability". Procedia-Social and Behavorial Sciences .Proceedings of 12th International Strategic Management Conference, ISMC 2016, 28-30 October 2016, Antalya, Turkey, Elsevier.

[9] S. Estrada, "Regional Differences in the Technological Conduct of Mexican Manufacturing Companies: The Case of Guanajuato". Economy, Society and Territory, 2006, 821-869.

[10] D. Kiran "Businesses Processes Reengineering". Chapter in Total Quality Management: Key Concepts and Case Studies, Elsevier, 2017.

[11] Hammer, M. (1990). Reengineering work: don't automate, obliterate. Harvard business review, 68(4), 104-112

[12] Herawan, T., Deris, M.M., \& Abawaj,J., (2013). Proceedings of the First International Conference on Advanced Data and Information Engieering (DaEng-2013). Springer Science+Business Media. ISSN 18761119

[13] E. Vidal, Organizational diagnosis: Systemic evaluation of business performance in the digital age. Colombia: ECOE Editions, 2004. (Original in Spanish: Diagnóstico organizacional: Evaluación sistémica del desempeño empresarial en la era digital)

[14] M. Porter. "Capital Disadvantage: America's Falling Capital Investment System”.Harvard Business Review, 77:6, November-December 1992.

[15] Savall H. and Zardet V. "Measures and Piloting of Social Responsibility and Company Society, Results of Longitudinal Investigations". Journal of International Institute of Costs, 4, january/june,2009.(Original in French: MESURE ET PILOTAGE DE LA RESPONSABILITÉ SOCIALE ET SOCIÉTALE DE L'ENTREPRISE -RÉSULTATS DE RECHERCHES LONGITUDINALES)

[16] Audirac, C., C. A,. León, E., V., Domínguez, G., A,. López, G., M. E. y Puerta, N., L.I “ABC of Organizational Development" Mexico :Trillas, 2012. (Original in Spanish: ABC del desarrollo Organizacional)

[17] Rojas, R "Guide to do social research". Mexico: Plaza and Valdes Editors, 2013. (Original in Spanish: Guía para realizar investigaciones sociales).

[18] Hernández, R., Fernández, C. y Baptista, M. del P. "Research Methodology". Mexico: McGraw-Hill, 2010. (Original in Spanish: Metodología de la investigación)

[19] P. Checkland, P. Systems Thinking, Systems Practice. New York: John Wiley and Sons, 1999.

[20] A. Delbecq, A. Van de Ven and D. Gustafson. Group Techniques for Program Planning. Chicago: Scott, Foresman, and Co, 1975.

[21] P. Drucker, P. The Practice of Management. New York: Harper Collins, 1954.

[22] Özge A and Erkut A. "The Effects Of Reengineering, Organizational Climate And Psychological Capital On The Firm Performance. ProcediaSocial and Behavorial Sciences. Proceedings of 12th International Strategic Management Conference, ISMC 2016, 28-30 October 2016, “Antalya, Turkey, Elsevier.

[23] Belay, E. T. Towards Bamboo Commercialization in Ethiopia: Analysis of Technology Sources, Innovation and Entrepreneurship Doctor. Technische Universität Dresden, 2015.

[24] Weerawardena, J "The Role of Marketing Capability in Innovation-Based Competitive Strategy", Journal of Strategic Marketing11, pp. 15-35, 2003. 